\title{
RACECADOTRIL IN ACUTE WATERY DIARRHEA IN CHILDREN
}

\author{
Maha Singh 1 , Alka Yadav², Sanjeev Nanda ${ }^{3}$ \\ ${ }^{1}$ Assistant Professor, Department of Paediatrics, SHKM Government Medical College, Nalhar Dist., Mewat, Haryana, India. \\ ${ }^{2}$ Assistant Professor, Department of Paediatrics, Pt. B. D. Sharma PGIMS, Rohtak, Haryana, India. \\ ${ }^{3}$ Senior Professor, Department of Paediatrics, Pt. B. D. Sharma PGIMS, Rohtak, Haryana, India.
}

ABSTRACT

\section{BACKGROUND}

Hypersecretory state of gut epithelium induced by toxins secreted by microorganisms is the main mechanism of fluid loss in diarrheal illness. Enkephalins (Endogenous Opioids) secreted by gut epithelium have marked pro-absorptive activity and are inactivated by enzyme enkephalinase. Racecadotril, the study drug act by augmenting the levels of enkephalins by inactivating enzyme enkephalinase thus leading to increased intestinal absorption.

\section{AIMS AND OBJECTIVES}

To study the efficacy of racecadotril in acute watery diarrhea in children.

\section{PARTICIPANTS}

Total of 100 patients who met inclusion criteria in the age group of 6 months to 5 years admitted with acute watery diarrhea and some dehydration were enrolment in the study. Cases were randomly divided into racecadotril and placebo group study outcomes in form of number of stools during first 48 hours of admission, mean daily stool number, total duration of diarrheal illness and recovery time, weight on discharge, volume of oral rehydration solution intake during hospital stay and requirement for unscheduled intravenous infusion were observed.

\section{RESULTS}

There was a significant decrease (43.9\%) in mean number of stools passed per day in racecadotril group when compared to placebo group. Secondary outcome variables, i.e. mean daily stool number, duration of diarrhea and recovery time, total volume of oral rehydration solution during study period, requirement for unscheduled intravenous infusion also showed a statically significant difference in two groups. Complications rates were not different in the two groups.

\section{CONCLUSION}

Racecadotril can be used as an adjunctive therapy in acute watery diarrhea.

\section{KEYWORDS}

Racecadotril, Enkephalinase Inhibitors, Moderate Dehydration, Antidiarrheal Drugs.

HOW TO CITE THIS ARTICLE: Singh M, Yadav A, Nanda S. Racecadotril in acute watery diarrhea in children. J Evolution Med Dent Sci 2016;5(6):301-304, DOI: 10.14260/jemds/2016/65

\section{INTRODUCTION}

Acute diarrhea is surpassed by respiratory infections only as a cause of morbidity in under five children on a world wide scale. An estimated 1.8 billion episodes of diarrhea occur each year. Around 3 million children under the age of 5 years die of diarrhea accounting for $15 \%$ of total under 5 deaths in developing countries.1,2 Driving forces operative in diarrhea are osmotic, secretory, exudative or motility disturbances. ${ }^{3}$ In almost all acute episodes of diarrhea, driving force is predominantly secretory with contribution from exudative and motility forces. Infections with bacteria and viruses cause diarrhea mainly through enterotoxins which activate secretory processes, cholera enterotoxin is the prototype toxin. ${ }^{4}$ Most of the deaths from acute infectious diarrhea result from excessive fluid or electrolyte losses that result in dehydration and acidosis. ${ }^{5}$

Financial or Other, Competing Interest: None

Submission 07-01-2016, Peer Review 08-01-2016,

Acceptance 14-01-2016, Published 19-01-2016.

Corresponding Author:

Dr. Alka Yadav,

Ho. No. 48/11J

Medical Campus,

Rohtak-124001.

E-mail: alkadv9@gmail.com

DOI: $10.14260 /$ jemds $/ 2016 / 65$
Children are more prone to complications of fluid loss due to diarrhea as compared to adults. Low osmolality WHO ORS is the corner stone of treatment of diarrhea. Aim of oral rehydration therapy is to correct and prevent dehydration. Around 90-95 percent of all cases of cholera and acute diarrhea can be treated by oral fluid alone. ${ }^{6}$ ORS is underused by caretakers as it does not reduce the duration, frequency and volume of diarrheal stools. Moreover a continuous rigorous compliance, motivation and basic level of understanding is mandatory for the desired outcome to ORS.

Racecadotril, an oral enkephalinase inhibitor was used in the treatment of acute diarrhea by some researchers based on the principle that it prevents the degradation of endogenous opioids (Enkephalins) responsible for hypersecretion of water and electrolytes into intestinal lumen. Racecadotril therefore decreases stool output without disturbing intestinal transit time. ${ }^{7}$ Racecadotril has been shown to be effective in reducing the stool output by almost half in young children with acute diarrhea by its anti-secretory action. ${ }^{8}$

\section{AIMS AND OBJECTIVES}

This present study was undertaken to evaluate the efficacy of racecadotril in acute watery diarrhea in children and to see whether this drug would lessen the acute complications like 
fluid loss and help in simplifying the management of acute watery diarrhea.

\section{MATERIAL AND METHODS}

The present study was carried out in the Paediatric Emergency Department of a Tertiary Care Hospital in North India over a period of one year. All the patients in the age group of 6 months to 5 years admitted with acute watery diarrhea and some dehydration as per WHO guidelines were evaluated for enrolment in the study. ${ }^{9} \mathrm{~A}$ detailed clinical history including baseline demographic information (Table 1), duration, frequency of stools, presence of blood or pus in stools and any treatment taken for the same episode and physical examination was performed for every patient. A total of 100 patients who fulfilled the inclusion criteria were selected for the study. An informed written consent was taken from the parents/guardians of all the patients included in the study.

\section{Study Design}

It was a prospective, randomized placebo controlled single blind trial.

\section{Inclusion Criteria}

Patients presented with acute watery diarrhea and having clinical signs of moderate/some dehydration were included in this study.

\section{Exclusion Criteria}

Patients presented with features of acute dysentery, severe dehydration, persistent vomiting, abdominal distension, sepsis, altered mental functions, severe malnutrition and those who had received any drug or intervention from outside prior to enrolment in the study were excluded.

\section{Method of Study \\ The patients selected as per inclusion criteria were randomly divided into two groups, Group A and Group B. Group A received racecadotril $(1.5 \mathrm{mg} / \mathrm{kg}$ body weight, orally three times a day for 5 days or until diarrhea stopped whichever came first) along with low osmolality oral rehydration solution and group B received low osmolality oral rehydration solution and a placebo. Continuous clinical monitoring along with routine investigations such as complete haemogram, blood urea and creatinine, blood sugar, serum electrolytes, Stool $(\mathrm{pH}$, microscopic examination, culture and sensitivity) were performed in all subjects.}

Primary outcome of the study was stool output in first 48 hours of admission as both fluid loss and risk of dehydration are maximal during this period. Clinical success was defined as resolution of diarrhea within 72 hours of initiation of study intervention. Diarrhea was considered to have stopped if patient had passed two consecutive formed stools or had not passed stools for last 12 hours. Observations were made till resolution of diarrhea or 5 days, whichever came first.

Other variables evaluated during the study were mean daily stool number, duration of diarrhea and recovery time, weight on discharge, total volume of oral rehydration solution during study period, requirement for unscheduled intravenous infusion and associated symptoms if any (Nausea, Anorexia, Pain Abdomen, Abdominal Distension).
These assessments were made till the time of recovery or at the end of 5 days, if the child had not recovered by that time. The results were analysed statistically using Student's t-test. Null hypothesis was rejected with level of significance $<0.05$.

\section{RESULTS}

Out of 100 patients enrolled, 50 patients each were allocated racecadotril group and placebo group (Group B). Both the groups were comparables in terms of the baseline demographic details as shown in Table 1. A statistically significant decreases in the stool output in first 48 hours was observed in patient's receiving racecadotril when compared to placebo. The total number of stools passed during the entire study period were also significantly lower in group A. In Group A six patients (12\%), while in group B 12 (24\%) patients continued to have diarrhea even after five days of admission (Treatment failure). Secondary outcome variables, i.e. mean daily stool number, duration of diarrhea and recovery time, total volume of oral rehydration solution during study period, requirement for unscheduled intravenous infusion also showed a statically significant difference in two groups as presented in Table 2 . The volume (mean \pm SD) of ORS taken during 1 st 48 hours of admission was significantly reduced in racecadotril group $(934 \pm 428.95 \mathrm{~mL}$ vs. $1515.55 \pm 679.53 \mathrm{~mL})$ as compared to placebo group (38.83 percent reduction).

The volume (mean \pm SD) ORS intake during entire study period in racecadotril group was also significantly lower $(1225.1 \pm 930.8)$ as compared to placebo group (2272.4 \pm 1546.4$)$. Duration of diarrhea was also significantly less in racecadotril group (53.28 \pm 32.03 hours) than placebo group (70.74 \pm 35.90 hours). The recovery time (mean \pm SD) in racecadotril group was $(44.18 \pm 21.53$ hours) and placebo group was (53.43 \pm 23.88 hours) and the difference was statically significant. Unscheduled intravenous fluid was required in $2(4 \%)$ patients in racecadotril group and 5 patients $(10 \%)$ in placebo group to maintain hydration due to high purge rate. Complications rate was not different in the two groups. The mean weight at discharge and weight gain during the study period was also not statically different in two groups (6.02\% vs $5.65 \%$, p >0.05).

\section{DISCUSSION}

Maximum stool output during any diarrheal illness is observed in first 48 hours so this period logically coincides with the development of dehydration and other diarrhea related complications. So any drug effective during this period would prove to be the most useful in preventing diarrhea related mortality and morbidity. Racecadotril acts by inhibiting an enzyme intestinal enkephalinase, preventing breakdown of enkephalins. Increased levels of endogenous opioids (Enkephalins) in intestinal mucosa acting through delta receptors lead to increased absorption of luminal fluids. Basal intestinal secretion and motility are not influenced by racecadotril. 10

Various studies have reported a variable effects of this drug in adults.11,12 There is growing data in children supporting racecadrotil use in acute diarrhea. Cojocaru et al. in a placebo controlled study on 166 children aged three months to three years found racecadotril effective in reducing number of stools in first 48 hours significantly as compared to placebo $(\mathrm{p}<0.001)$ irrespective of the mode of rehydration (Intravenous or oral). ${ }^{13}$ 
Assessment of loss of fluid during diarrhea by observing the total number of stools in a stipulated time is an indirect method and correlates well with the findings seen in studies where fluid loss was measured directly by weighing each stool. Salazar et al. in 135 boys in the age group of 3 to 35 months, showed that racecadotril decreased mean 48-hour stool output significantly $(46 \%, \mathrm{p}<0.001)$. Only boys were included in this study deliberately to avoid mixing of urine while collecting stools. Mean stool output was $1.8 \pm 0.2 \mathrm{gm} / \mathrm{kg}$ body weight/hour and $3.1 \pm 0.3 \mathrm{gm} / \mathrm{kg}$ bodyweight/hour in the racecadotril and placebo group respectively $(\mathrm{p}<0.001) .{ }^{14}$ Baumer et al. and Cezard et al. also showed similar results. ${ }^{15,16}$ Results of present study have established the efficacy of racecadotril in decreasing number of stools passed during first 48 hours significantly. Further our results favors that action of the drug starts immediately. Comparison of number of stools passed during entire study revealed a significant decrease in racecadotril group implying that racecadotril remains effective as long as hypersecretion state of the gut is maintained by enterotoxins.

Amount of fluid intake by the patient is directly proportional to the amount of fluid lost from the body. In acute watery diarrhea evaluation of this variable indirectly measures the effect of the intervention on stool output. Racecadotril reduced the mean oral rehydration solution intake significantly in our study. Similar results were reported statistically significant decrease of $33 \%$ on day 1 and $35 \%$ on day 2 by Salazar et al. in their study. ${ }^{14}$

We observed that racecadotril shortens the duration of diarrhea by 17.46 hours in the present study. Median duration of diarrhea was also significantly less $(\mathrm{p}<0.001)$ in racecadotril treated group (28 hours in both Rota virus positive and negative boys) in a study conducted by Salazar et al. ${ }^{14}$ Recovery time of acute watery diarrhea is indirectly related to the duration of diarrhea. Racecadotril hastens the recovery from acute watery diarrhea. Cojocaru et al. reported that repeat emergency department visits by patients after treatment with racecadotril were significantly reduced, which indirectly supports the findings that racecadotril shortens the duration of diarrhea. 13

\section{CONCLUSIONS}

Based upon the findings in the present study, it is therefore concluded that racecadotril is effective in decreasing number of stools and oral rehydration solution requirement in acute watery diarrhea in children. Duration of diarrhea and recovery time of the illness was also shortened. Racecadotril may be used as an adjunctive therapy in addition to the standard treatment in the form of ORT, oral supplementation of zinc, nutritional management and antibiotics where ever indicated. So far only a small number of clinical trials have been conducted.
Therefore better structured trials are necessary before racecadotril can be recommended for treatment of diarrhea.

\section{REFERENCES}

1. WHO (1999). Health situation in South East Asia. Vol. III, 2001-2004.

2. WHO. World Health Report 1999 making a difference, Geneva, WHO, 1999.

3. Field M. Intestinal ion transport and pathophysiology of diarrhoea. J Clin Invest 2003;111(7):931-43.

4. Christie AB. Infectious diseases: epidemiology and clinical practice. $3^{\text {rd }}$ ed. Churchill Livingstone. 1980.

5. Farthing MJG. Novel targets for control of secretory. Diarrhoea; Gut 2002;50:15-8.

6. Dc S. Management of cholera with oral rehydration solution. J Com Dis 1975;7:124-8.

7. Primi MP, Burno L, Baumer P, et al. Racecadotril demonstrates intestinal antisecretory activity in vivo. Aliment Pharmacol Ther 1999;13:63-7.

8. Salazar-Lindo E, Santisteban-Pouce J, Chea Woo E, et al. Racecadotril in treatment of acute watery diarrhoea in children. N Eng J Med 2000;343(7):463-7.

9. Cassuto J, Jodal M, Tuttle R. Hydroxytryptamine and cholera secretion. Physiological and pharmacological studies in cats and rats. Scand J Gastroenterol 1982;17:695-703.

10. Hinterbitner TA, Petritsch W, Dimsity G, et al. Acetorphan prevents cholera induced water and electrolyte secretion in human jejunum. Eur J Gastroenterol Hepatol 1997;9:887-92.

11. Hamza H, Khalifa H, Baumer P, et al. Racecadotril versus placebo in the treatment of acute diarrhoea in adults. Aliment Pharmacol Ther 1999;13(6):15-9.

12. Alam NH, Ashraf $\mathrm{H}$, Khan WA, et al. Efficacy and tolerability of racecadotril in the treatment of cholera in adults: a double blind, randomized, controlled clinical trial. Gut 2003;52(10):1419-23.

13. Cojocaru B, Bocquet N, Timsit S, et al. Effect of racecadotril in the management of acute diarrhoea in infants and children. Arch Pediatr 2002;9(8):774-9.

14. Salaza-Lindo E, Santisteban-Ponce J, Chea Woo E, et al. Racecadotril in the treatment of acute watery diarrhoea in children. N Eng J Med 2000;343:463-7.

15. Baumer P, Danquechin Dorval E, Bertrand J, et al. Effect of acetorphan; an enkephalinase inhibitor, on experimental and acute diarrhoea. Gut 1992;33:753-8.

16. Cezard JP, Duhamel JF, Meyer M, et al. Efficacy and tolerability of racecadotril in acute diarrhoea in children. Gastroenterol 2001;120(4):799-805.

\begin{tabular}{|c|c|c|}
\hline Sex & $\begin{array}{c}\text { Group A } \\
\text { No. of Cases (\%) }\end{array}$ & $\begin{array}{c}\text { Group B } \\
\text { No. of Cases (\%) }\end{array}$ \\
\hline Male & $26(52 \%)$ & $24(48 \%)$ \\
\hline Female & $24(48 \%)$ & $26(52 \%)$ \\
\hline Mean weight at admission (Kgs) & $10.62 \pm 3.18$ & $10.66 \pm 3.25$ \\
\hline Mean age (Months) & $19.93 \pm 14.15$ & $19.47 \pm 16.49$ \\
\hline Mean height (cm) & $79.81 \pm 12.3$ & $78.25 \pm 13.4$ \\
\hline \multicolumn{2}{|c|}{ Table 1: Baseline demographic profile of the study groups } \\
\hline
\end{tabular}




\begin{tabular}{|c|c|c|c|}
\hline Study Variable & Group A & Group B & P value \\
\hline $\begin{array}{c}\text { Stools passed in 1st } \\
48 \text { hours (mean } \pm \text { SD) }\end{array}$ & $8.74 \pm 3.45$ & $13.8 \pm 4.34$ & $\mathrm{p}<0.001$ \\
\hline $\begin{array}{c}\text { Stools passed during entire } \\
\text { study period (mean } \pm \text { SD) }\end{array}$ & $11.78 \pm 8.79$ & $21 \pm 11.33$ & $\mathrm{p}<0.001$ \\
\hline $\begin{array}{c}\text { ORS intake during 1st } \\
48 \text { hours (mean } \pm \text { SD) }\end{array}$ & $934 \pm 428.95 \mathrm{~mL}$ & $1515.55 \pm 679.53 \mathrm{~mL}$ & $\mathrm{p}<0.001$ \\
\hline $\begin{array}{c}\text { ORS intake during entire } \\
\text { study period (mean } \pm \text { SD) }\end{array}$ & $1225.1 \pm 930.8 \mathrm{~mL}$ & $2272.4 \pm 1546.4 \mathrm{ml}$ & $\mathrm{p}<0.001$ \\
\hline $\begin{array}{c}\text { Duration of } \\
\text { diarrhea (mean } \pm \text { SD) }\end{array}$ & $53.28 \pm 32.03$ hours & $70.74 \pm 35.90$ hours & $\mathrm{p}<0.05$ \\
\hline $\begin{array}{c}\text { Treatment failure } \\
\text { at end of 5th day }\end{array}$ & $6(12 \%)$ & $12(24 \%)$ & $\mathrm{p}<0.001$ \\
\hline Mean recovery time & $44.18 \pm 21.53$ hours & $53.43 \pm 23.88$ hours & $\mathrm{p}<0.001$ \\
\hline $\begin{array}{c}\text { Unscheduled intravenous } \\
\text { fluid requirements }\end{array}$ & $2(4 \%)$ & $5(10 \%)$ & $\mathrm{p}<0.05$ \\
\hline $\begin{array}{c}\text { Mean weight at } \\
\text { discharge (kgs) }\end{array}$ & $11.26 \pm 3.32$ & $11.24 \pm 3.3$ & $\mathrm{P}>0.05$ \\
\hline \multicolumn{2}{|c|}{ Table 2: Primary and secondary outcome variables in study groups } \\
\hline
\end{tabular}

